\title{
Associations Between Kidney Dysfunction and Risk Factors in Patients with Transurethral Resection of the Prostate
}

\author{
Zuhirman Zamzami $\mathbb{D}^{\prime}$ \\ Herman Rayendra ${ }^{2}$ \\ Nafisa Az-zahra ${ }^{3}$ \\ 'Urology Division, Surgery Department, \\ Medical Faculty of Riau University, \\ Pekanbaru, Riau, Indonesia; ${ }^{2}$ Department \\ of Internal Medicine, Consultant of \\ Kidney and Hypertension, Medical \\ Faculty of Riau University, Pekanbaru, \\ Riau, Indonesia; ${ }^{3}$ Medical Faculty of Riau \\ University, Pekanbaru, Riau, Indonesia
}

Correspondence: Zuhirman Zamzam Urology Division, Surgery Department, Medical Faculty of Riau University, I Jalan Diponegoro, Pekanbaru, Riau 28133, Indonesia

Tel +62 81 2-754-9988

Fax +62 076। 40644

Email zuhirman.zamzami@yahoo.com
Purpose: Benign prostate hyperplasia $(\mathrm{BPH})$ with urinary retention can result in kidney dysfunction. Several risk factors might influence deterioration in kidney function. The aims of this study were to assess the association between kidney dysfunction and risk factors in patients with transurethral resection of the prostate (TURP).

Methods: We reviewed medical records of BPH patients managed by TURP and having high levels of blood urea and creatinine. Data collected were age, history of hypertension, diabetes mellitus (DM), urinary tract infection (UTI), urinary retention, and urinary tract stones, duration of obstruction, and blood-urea and -creatinine levels before and after TURP. Chi-suare and paired $t$ - tests were used.

Results: There were 64 patients in the study. More were aged 60-69 years $(42.2 \%)$ than other age-groups, $53.1 \%$ had a history of hypertension, $12.5 \% \mathrm{DM}, 35.9 \% \mathrm{UTI}$, all urinary retention, $14.1 \%$ urinary tract stones, and $92.2 \%$ obstruction duration $<14$ days. There were significant differences in blood-urea and -creatinine levels between before and after TURP $(p<0.001)$. There were no significant differences between age-group, hypertension, DM, UTI, urinary retention, urinary stones, or duration of obstruction with kidney dysfunction after TURP $(p>0.001)$.

Conclusion: Age, hypertension, DM, UTI, urinary retention, urinary tract stones, and duration of obstruction can be risk factors of kidney dysfunction in TURP patients, and TURP might improve blood-urea and -creatinine levels. There was no significant association between kidney recovery and kidney dysfunction with the number of risk factors in TURP and pre-TURP patients.

Keywords: BPH, TURP, risk factor, blood-urea level, blood-creatinine level, kidney dysfunction

\section{Introduction}

Benign prostate hyperplasia (BPH) is the second-most common disease in urology clinics in Indonesia. In Pekanbaru, BPH is the most common pathology in urology clinics. We found 456 BPH cases in 2011-2014 in Arifin Achmad Hospital, Riau Province. ${ }^{1}$

The prevalence of BPH histopathology in autopsy studies increased from around $20 \%$ in men aged $41-50$ years to $50 \%$ in men aged $51-60$ years and $>90 \%$ in men over 80 years old. In 55-year-olds, about $25 \%$ experience obstructive symptoms when urinating. In 75-year-olds, 50\% complain of a decrease in the strength and caliber of urinary flow. ${ }^{2}$ 
Risk factors of BPH are age 40 years or older, family history of BPH, obesity, heart disease, circulatory disorders, type 2 diabetes mellitus (DM), lack of exercise, and erectile dysfunction. ${ }^{3}$ In addition, BPH patients with erectile dysfunction also exhibit comorbiditiies. ${ }^{6}$ Comorbidity of metabolic syndrome has a strong association with increased incidence of $\mathrm{BPH} /$ lower urinary tract symptoms (LUTSs), especially in patients with DM, hypertension, and obesity. ${ }^{4}$

Transurethral resection of the prostate (TURP) has been the gold standard for endoscopic surgical therapy for BPH for $>30$ years. ${ }^{5}$ TURP is an operation to remove enlarged parts of the prostate gland, causing the urethra to become depressed. This is the most common type of surgery to treat prostate enlargement. ${ }^{6}$ In Arifin Achmad Hospital in 2009-2010, there were 122 cases of BPH that had undergone TURP. ${ }^{7}$ Although TURP is the main choice in BPH therapy, the possibility of complications is unavoidable. ${ }^{1}$

Impaired kidney function might occur because of complications due to BPH. Disorders of kidney function include acute kidney injury (AKI), chronic kidney disease (CKD), and AKI with CKD. ${ }^{8}$ AKI is a condition in which the glomerular filtration rate is abruptly reduced, causing a sudden retention of endogenous and exogenous metabolites (eg, urea, potassium, phosphate, and sulfate) that are normally cleared by the kidneys. Causes of AKI are prerenal, functional hemodynamic, vascular, parenchymal intrarenal, and postrenal one. BPH has a postrenal cause. ${ }^{8}$ If $\mathrm{BPH}$ is not managed properly, it can lead to complications in the form of acute urinary retention, chronic kidney failure, recurrent urinary tract infections, bladder decompensation, ${ }^{9}$ hematuria, and kidney insufficiency. ${ }^{10}$ Potential causes of CKD include DM, hypertension, autoimmune diseases, systemic infections, urinary tract infections, urinary tract stones, LUT obstruction, neoplasma, family history of CKD, recovery from previous AKI, kidney-mass reduction, exposure to certain drugs (antihypertensive), and low birth weight. ${ }^{11}$

\section{Methods}

This was a retrospective descriptive study. We reviewed the medical records of patients with kidney-function impairment who had underwentgone TURP in the Urology Department of Arifin Achmad Hospital from January 2013 to December 2017. Data collected were age, history of hypertension, DM, urinary tract infection, urinary retention, urinary tract stones, duration of obstruction, and blood-urea and -creatinine levels on laboratory results before and after TURP. BPH with urinary retention is an indication for TURP, which is the gold standard of management. Statistical analysis used were Chi-square and paired $t$-tests. Study approval was obtained from the Ethical Review Board for Medicine and Health Research, Medical Faculty, Riau University.

\section{Results}

There were 64 patients in this study. The largest age-group was 60 - to 69 -year-olds $(27,42.2 \%)$ and the smallest 40 to 49 -year-olds (one, $1.6 \%)$. There were $34(53.1 \%)$ patients with a history of hypertension and 30 (46.9\%) who did not. There were eight (12.5\%) patients with a history of DM and $56(87.5 \%)$ who did not. There were $23(35.9 \%)$ patients with a history of urinary tract infections and $41(64.1 \%)$ who did not, whereas all study patients had a history of urinary retention. There were nine (14.1\%) patients with a history of urinary tract stones and $55(85.9 \%)$ who did not. A majority of patients had had obstruction $<14$ days in $(59,92.2 \%)$ and five $(7.8 \%)>14$ days. (Table 1).

Analysis with paired $t$-tests (Table 2) was carried out to determine differences between blood-urea and -creatinine levels before and after TURP. Blood-urea levels showed a mean of 47.17 before TURP and 35.67 after TURP, and creatinine levels 1.82 before TURP and 1.10 after TURP. Urea levels showed $t=6.26$ and creatinine levels $t=10.12$. There were significant differences $(p=0.001)$ between urea and creatinine levels before and after TURP.

There were no significant associations of age-group ( $p=0.277)$, history of hypertension $(p=0.97)$, history of DM ( $p=0.183)$, history of UTI ( $p=0.356)$, history of urinary retention (NA), history of urinary stones $(p=0.670)$, or duration of obstruction $(p=0.277)$ with recovery of urea levels after TURP (Table 3 ).

Table 4 shows that there were no significant associations of age-group $(p=0.277)$, history of hypertension $(p=0.97)$, history of DM $(p=0.183)$, history of UTI $(p=0.356)$, history of urinary retention (NA), history of urinary tract stones $(p=0.670)$, or duration of obstruction $(p=0.277)$ with recovery of creatinine levels after TURP.

Table 5 shows that there were no significant associations of age-group $(p=0.277)$, history of hypertension $(p=0.230)$, history of DM $(p=0.128)$, history of UTI $(p=0.768)$, history of urinary retention (NA), history of urinary tract stones $(p=0.670)$, or duration of obstruction ( $p=0.218$ ) with kidney dysfunction (urea levels) before 
Table I Risk factors

\begin{tabular}{|c|c|c|}
\hline Age-group (years) & $\mathbf{n}$ & $\%$ \\
\hline $40-49$ & 1 & 1.6 \\
\hline $50-59$ & 10 & 15.6 \\
\hline $60-69$ & 27 & 42.2 \\
\hline 70-79 & 19 & 29.7 \\
\hline$>80$ & 7 & 10.9 \\
\hline Total & 64 & 100 \\
\hline \multicolumn{3}{|l|}{ History of hypertension } \\
\hline Yes & 34 & 53.1 \\
\hline No & 30 & 46.9 \\
\hline Total & 64 & 100 \\
\hline \multicolumn{3}{|l|}{ History of DM } \\
\hline Present & 8 & 12.5 \\
\hline Absent & 56 & 87.5 \\
\hline Total & 64 & 100 \\
\hline \multicolumn{3}{|l|}{ History of UTI } \\
\hline Present & 23 & 35.9 \\
\hline Absent & 41 & 64.1 \\
\hline Total & 64 & 100 \\
\hline \multicolumn{3}{|l|}{ History of urinary retention } \\
\hline Present & 64 & 100 \\
\hline Absent & 0 & \\
\hline Total & 64 & 100 \\
\hline \multicolumn{3}{|l|}{ History of urinary tract stones } \\
\hline Present & 9 & 14.1 \\
\hline Absent & 55 & 85.9 \\
\hline Total & 64 & 100 \\
\hline \multicolumn{3}{|l|}{ Duration of obstruction (days) } \\
\hline$<14$ & 59 & 92.2 \\
\hline$\geq 14$ & 5 & 7.8 \\
\hline Total & 64 & 100 \\
\hline
\end{tabular}

Table 2 Blood-urea and -creatinine levels before and after TURP

\begin{tabular}{|l|c|c|c|c|}
\hline & n & Mean & $t$ & $p$ \\
\hline Blood urea \\
\hline $\begin{array}{l}\text { Before TURP } \\
\text { After TURP }\end{array}$ & 64 & $\begin{array}{l}47.17 \\
35.67\end{array}$ & 6.26 & 0.001 \\
\hline \multicolumn{5}{|l}{ Blood creatinine } \\
\hline Before TURP & 64 & 1.82 & 10.12 & 0.001 \\
After TURP & 64 & 1.10 & & \\
\hline
\end{tabular}

Table 3 Relationship between risk factors and renal recovery based on urea levels after TURP

\begin{tabular}{|c|c|c|c|}
\hline & \multicolumn{2}{|c|}{ Renal recovery (urea) } & \multirow[t]{2}{*}{$p$} \\
\hline & Normal & High & \\
\hline \multicolumn{4}{|l|}{ Age-group (years) } \\
\hline$<40$ & $4(57.1 \%)$ & $3(42.9 \%)$ & 0.277 \\
\hline $40-49$ & $\mathrm{I}(100 \%)$ & 0 & \\
\hline $50-59$ & $10(100 \%)$ & 0 & \\
\hline $60-69$ & $2 \mathrm{I}(77.8 \%)$ & $6(22.2 \%)$ & \\
\hline 70-79 & |4(73.7\%) & $5(26.3 \%)$ & \\
\hline \multicolumn{4}{|l|}{$\begin{array}{l}\text { History of } \\
\text { hypertension }\end{array}$} \\
\hline Yes & $26(76.5 \%)$ & $8(23.5 \%)$ & 0.97 \\
\hline No & $24(80 \%)$ & $0(20 \%)$ & \\
\hline \multicolumn{4}{|l|}{ History of DM } \\
\hline Yes & $8(100 \%)$ & 0 & 0.183 \\
\hline No & $42(75 \%)$ & $14(25 \%)$ & \\
\hline \multicolumn{4}{|l|}{ History of UTI } \\
\hline Yes & $16(69.9 \%)$ & $7(30.4 \%)$ & 0.356 \\
\hline No & $34(82.9 \%)$ & $7(7.17 \%)$ & \\
\hline \multicolumn{4}{|l|}{$\begin{array}{l}\text { History of urinary } \\
\text { retention }\end{array}$} \\
\hline Yes & $50(78.1 \%)$ & $14(21.9)$ & NA \\
\hline No & - & - & \\
\hline \multicolumn{4}{|l|}{$\begin{array}{l}\text { History of urinary } \\
\text { stones }\end{array}$} \\
\hline Yes & $8(88.9 \%)$ & $\mathrm{I}(\mathrm{I} / \%)$ & 0.670 \\
\hline No & $42(76.4 \%)$ & $13(23.6 \%)$ & \\
\hline \multicolumn{4}{|l|}{$\begin{array}{l}\text { Duration of } \\
\text { obstruction (days) }\end{array}$} \\
\hline$<14$ & $45(76.3 \%)$ & $14(23.7 \%)$ & 0.277 \\
\hline$\geq 14$ & $5(100 \%)$ & 0 & \\
\hline
\end{tabular}

Note: $p<0.001$.

Abbreviation: NA, not analyzed.

TURP. Table 5 also shows that the chances of influencing kidney-dysfunction occurrence before TURP were 0.4 based on history of hypertension (OR 0.477), 0.1 based on history of DM (OR 0.153), 0.3 based on history of UTI $(p=0.768)$ and urinary retention (NA), 0.6 times based on urinary tract stones (OR 0.6 ) and 0.1 based on duration of obstruction (OR 0.17) that of kidney-dysfunction (urea levels) before TURP.

Table 6 shows that there were no significant associations of age-group ( $p=0.846$ ), history of hypertension $(p=1)$, history of DM $(p=0.128)$, history of UTI $(p=0.768)$, history of urinary retention (NA), history of urinary tract stones $(p=1)$, or duration of obstruction 
Table 4 Relationship between risk factors and renal recovery based on creatinine levels after TURP

\begin{tabular}{|c|c|c|c|}
\hline & \multicolumn{2}{|c|}{$\begin{array}{c}\text { Renal recovery } \\
\text { (creatinine) }\end{array}$} & \multirow[t]{2}{*}{$p$} \\
\hline & Normal & High & \\
\hline \multicolumn{4}{|l|}{ Age-group (years) } \\
\hline$<40$ & $6(85.7 \%)$ & 0 & 0.947 \\
\hline $40-49$ & $\mathrm{I}(100 \%)$ & 0 & \\
\hline $50-59$ & $9(90 \%)$ & $\mathrm{I}(\mathrm{I0 \%})$ & \\
\hline $60-69$ & $25(92.6 \%)$ & $2(7.4 \%)$ & \\
\hline $70-79$ & $18(94.7 \%)$ & $\mathrm{I}(5.3 \%)$ & \\
\hline \multicolumn{4}{|l|}{ History of hypertension } \\
\hline Yes & $31(91.2 \%)$ & $3(8.8 \%)$ & 1 \\
\hline No & $28(93.3 \%)$ & $2(6.7 \%)$ & \\
\hline \multicolumn{4}{|l|}{ History of DM } \\
\hline Yes & $8(100 \%)$ & 0 & 0.860 \\
\hline No & $\mathrm{I}(\mathrm{I} 2.5 \%)$ & $8(100 \%)$ & \\
\hline \multicolumn{4}{|l|}{ History of UTI } \\
\hline Yes & $19(82.6 \%)$ & $4(17.4 \%)$ & 0.052 \\
\hline No & $40(97.6 \%)$ & $\mathrm{I}(2.4 \%)$ & \\
\hline \multicolumn{4}{|l|}{ History of urinary retention } \\
\hline Yes & $59(92.2 \%)$ & $5(7.8 \%)$ & NA \\
\hline No & - & - & \\
\hline \multicolumn{4}{|l|}{ History of urinary stones } \\
\hline Yes & $8(88.9 \%)$ & $\mathrm{I}(\mathrm{II} \%)$ & 0.544 \\
\hline No & $51(92.7 \%)$ & $4(7.3 \%)$ & \\
\hline \multicolumn{4}{|l|}{ Duration of obstruction (days) } \\
\hline$<14$ & $54(91.5 \%)$ & $5(8.5 \%)$ & 1 \\
\hline$\geq 14$ & $5(100 \%)$ & 0 & \\
\hline
\end{tabular}

Note: $p<0.005$.

Abbreviation: NA, not analyzed.

( $p=0.218$ ) with kidney dysfunction (creatinine levels) before TURP. Table 5 The chances of influencing kidney-dysfunction occurrence before TURP were not analyzed.

\section{Discussion}

Those aged 60-69 years were most likely to have impaired kidney function (27 patients, $42.2 \%$ ). There was an association between BPH and increased age: decreased male hormone levels, especially testosterone, ${ }^{11,12}$ leading to a significant reduction in kidney function. ${ }^{13}$ Hidayati found BPH in TURP patients was mostly in 60- 69-yearold group (21 patients, 50\%). ${ }^{14}$ The 2006 National Health and Nutrition Examination Survey found that the most predominant age-group exhibiting CKD was those aged
60 years and over $(39.4 \%)$, followed by $40-59$ years $(12.6 \%)$ and $20-39$ years $(8.5 \%){ }^{15}$

High blood pressure might result in kidney function declining until kidney failure. ${ }^{16}$ In this study, there were $34(53.1 \%)$ patients with a history of hypertension, in line with a study that showed risk factors of chronic kidneyfunction disorders: of 100 subjects, 45 (45\%) had hypertension. ${ }^{17}$ Adhiatama et al found that $23(63.9 \%)$ patients had a history of hypertension in chronic kidney failure. ${ }^{18}$ Hervinda found that $126(68.9 \%)$ patients had a history of hypertension with CKD. ${ }^{19}$

In this study there were eight (12.5\%) patients who had a history of DM. This is in line with the Adhiatama et al, who found eight $(1.9 \%)$ patients with CKD with a history of DM, ${ }^{19}$ and also in line with Hervinda, who found $33.3 \%$ of CKD patients with a history of high DM. ${ }^{20}$ DM results in decreased kidney-filtering function, resulting in the body gaining a lot of waste. If this continues, it will cause chronic kidney failure. ${ }^{19}$

This study showed UTI history in 23 (35.9\%) patients. UTI is one of the risk factors of CKD. The occurrence of UTI accompanied by vesicoureteral reflux can increase scar formation in the kidneys, which results in a decrease in kidney function. ${ }^{17,21}$ This result is in line with Hsiao, who showed that $46.4 \%$ of patients with AKI had a history of upper UTI, ${ }^{22}$ anda study of 100 patients diagnosed with acute pyelonephritis (upper UTI), where 47 (47\%) patients had AKI. ${ }^{23}$ However, our result was not in line with Rollino et al, who found that of 223 patients with pyelonephritis, only $21(9.4 \%)$ had AKI. ${ }^{24}$ Our result was also different from Hervinda, who found 26 (14.2\%) patients of 183 with a history of UTI. ${ }^{20}$

We found that all patients had a history of urinary retention. Men aged 50-60 years are prone to urinary retention in BPH. In some people, urinary retention can cause kidney damage because of the backflow of urine to the kidneys, which can cause scarring of the kidneys. ${ }^{25}$ Our result was in line with Vaidyanathan for the increase in temperature., ${ }^{26}$ Speakman found chronic urinary retention was a major cause of CKD in patients with LUTSs/BPH. Imaging tests should be done to assess hydronephrosis and measure serum eGFR and creatinine. It is possible to treat renal dysfunction with TURP so it can improve post-TURP kidney function. ${ }^{27}$

There were nine $(14.1 \%)$ people with urinary stone history. Obstruction caused by urinary tract stones can cause an increase in intratubular pressure, followed by vasoconstriction of blood vessels causing ischemia in the kidneys. Long-term ischemia can cause 
Table 5 Association between risk factors and renal dysfunction based on urea levels

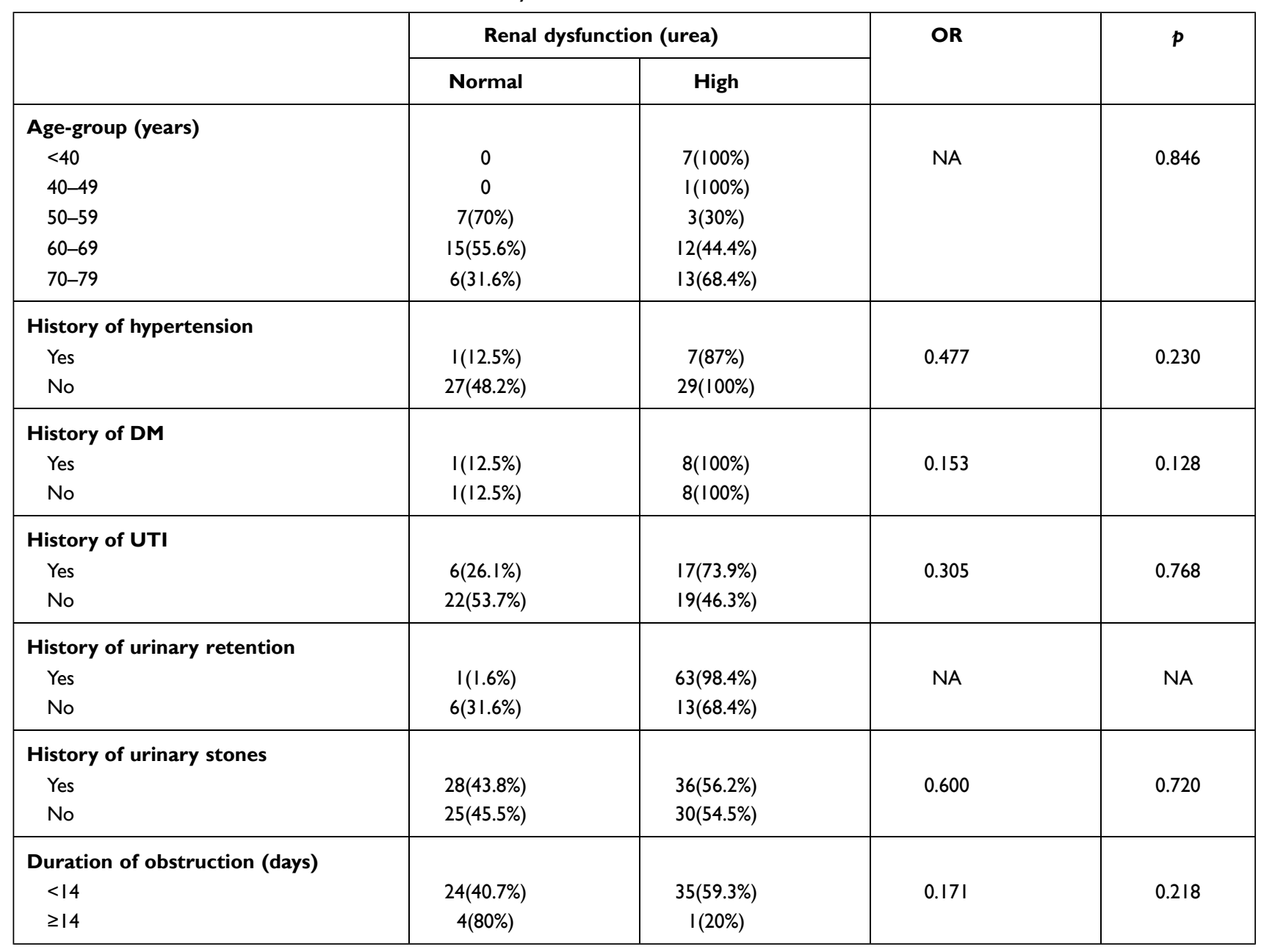

Note: $p<0.001$.

Abbreviation: NA, not analyzed.

glomerulosclerosis, tubular atrophy, and interstitial fibrosis. ${ }^{28}$ Our results are in line with Hervinda et al, who found that in $182 \mathrm{CKD}$ patients, 21 (11.5\%) had a history of urinary tract stones, ${ }^{20}$ and Kartha et al, who found $0.8 \%-17.5 \%$ of CKD patients with urinary tract stone disease. ${ }^{29}$

We found that patients with renal dysfunction had a duration of obstruction $<14$ days, or acute obstruction in $59(92.2 \%)$ patients, and those with $>14$ days or chronic obstruction numbered five (7.8\%). Obstructive uropathy is anatomical and functional obstruction in all levels of the urinary tract: from the kidney, ureter, and bladder to the urethra. ${ }^{30}$ If the obstruction persists or is chronic, the pelvic and calyx of the kidney dilate, representing hydronephrosis. ${ }^{31}$ Damage to nephrons that undergo hydronephrosis depends on blockage degree, duration of obstruction, renal pelvic anatomy, degree of disruption of blood vessels, and presence or absence of concomitant infections. $^{32}$

Blood-urea levels can identify a decrease in kidney function. ${ }^{33} \mathrm{~A}$ decline in kidney function might be also identified based on blood-creatinine levels. ${ }^{34} \mathrm{We}$ found that there was a significant difference between bloodurea and -creatinine levels $(p=0.001)$ before and after TURP. This result is in line with Zamzami, who examined urinary and creatinine levels in obstructive uropathy patients who experienced BPH after undergoing TURP. In that study also, there was a significant difference between urea levels before and after TURP $(p<0.001){ }^{35}$

Our research also supports the results of Riyach et al in men aged $\geq 65$ years who had prostate enlargement and impaired kidney function with blood-urea levels of 
Table 6 Association between risk factors and renal dysfunction based on creatinine levels

\begin{tabular}{|c|c|c|c|c|}
\hline & \multicolumn{2}{|c|}{ Renal dysfunction (creatinine) } & \multirow[t]{2}{*}{ OR } & \multirow[t]{2}{*}{$p$} \\
\hline & Normal & High & & \\
\hline \multicolumn{5}{|c|}{ Age-group (years) } \\
\hline$<40$ & 0 & $\mathrm{I}(2.8 \%)$ & NA & 0.846 \\
\hline $40-49$ & 0 & $10(15.9 \%)$ & & \\
\hline $50-59$ & $\mathrm{I}(100 \%)$ & $26(41.3 \%)$ & & \\
\hline $60-69$ & 0 & $19(30.2 \%)$ & & \\
\hline $70-79$ & 0 & $7(11.1 \%)$ & & \\
\hline \multicolumn{5}{|c|}{ History of hypertension } \\
\hline Yes & $\mathrm{I}(2.9 \%)$ & $33(97.1 \%)$ & NA & I \\
\hline No & 0 & $30(100 \%)$ & & \\
\hline \multicolumn{5}{|c|}{ History of DM } \\
\hline Yes & $0(12.5 \%)$ & $8(100 \%)$ & NA & 0.128 \\
\hline No & $22(53.7 \%)$ & $29(51.8 \%)$ & & \\
\hline \multicolumn{5}{|c|}{ History of UTI } \\
\hline Yes & $\mathrm{I}(4.3 \%)$ & $22(95.7 \%)$ & NA & 0.768 \\
\hline No & 0 & $4 I(100 \%)$ & & \\
\hline \multicolumn{5}{|c|}{ History of urinary retention } \\
\hline Yes & $\mathrm{I}(\mathrm{I} .6 \%)$ & $63(98.4 \%)$ & NA & 0.020 \\
\hline No & $6(31.6 \%)$ & $13(68.4 \%)$ & & \\
\hline \multicolumn{5}{|c|}{ History of urinary stones } \\
\hline Yes & 0 & $9(100 \%)$ & NA & \\
\hline No & $25(45.5 \%)$ & $30(54.5 \%)$ & & \\
\hline \multicolumn{5}{|c|}{ Duration of obstruction (days) } \\
\hline$<14$ & $24(40.7 \%)$ & $35(59.3 \%)$ & NA & \\
\hline$\geq 14$ & $4(80 \%)$ & $\mathrm{I}(20 \%)$ & & \\
\hline
\end{tabular}

Note: $p<0.001$.

Abbreviation: NA, not analyzed.

$43.5 \mathrm{mg} / \mathrm{dL}$. After surgery and being observed for 3 months, patients were able to urinate well and showed no decrease in kidney function. ${ }^{36}$ The results of this study have similarities with Thasinas et al, who found that there was a change in blood-urea levels after surgery. ${ }^{37}$ Zamzami also found a significant difference in creatinine levels before and after TURP. ${ }^{37}$ Our results were also in line with Amar, who found patient creatinine levels on the second day after surgery were $1.6 \pm 0.2 \mathrm{mg} / \mathrm{dL}$ and $1.56 \mathrm{mg} / \mathrm{dL}$ on day 14 , and remained constant until 6 weeks after surgery. ${ }^{38,39}$

There were no significant associations between agegroup, history of hypertension, history of DM, history of UTI, history of urinary retention, history of urinary tract stones, or duration of obstruction with recovery of urea levels after TURP. Also, there were no significant associations between age-group, history of hypertension, history of DM, history of UTI, history of urinary retention, history of urinary tract stones, or duration of obstruction with recovery of creatinine levels after TURP. We concluded that there was no significant association between kidney recovery and risk factors in TURP patients.

There were no significant differences between agegroup, history of hypertension, history of DM, history of UTI, history of urinary retention, history of urinary tract stones, or duration of obstruction with kidney dysfunction (urea levels) before TURP. The chances of influencing kidney-dysfunction occurrence before TURP were 0.4 times for history of hypertension, 0.1 times for history of DM, 0.3 times for history of UTI, history of urinary retention, 0.6 times for history of urinary tract stones, and 0.1 times for duration of obstruction with kidney dysfunction (urea levels) before TURP. 
There were no significant differences between agegroup, history of hypertension, history of DM, history of UTI, history of urinary retention, history of urinary tract stones, or duration of obstruction with kidney dysfunction (creatinine levels) before TURP. It was concluded that there was no significant association between renal dysfunction and number of risk factors in pre-TURP patients and little chance of an influence on kidney dysfunction (urea levels) occurrence in patients with TURP. Sarier et al showed that TURP can be safely and successfully applied for the treatment of BPH after renal transplant, and also that LUTSs and renal function significantly improve after the operation. ${ }^{40}$ Volpe et al showed that TURP for LUT obstruction attributable to BPH in renal transplantation is safe and effective, since it improves urinary flow, bladder emptying, and related urinary symptoms. TURP affords an early significant improvement in graft function that is maintained at 48 months. $^{41}$

\section{Conclusion}

Age, history of hypertension, DM, urinary tract infections, urinary retention, urinary tract stones, and duration of obstruction can be risk factors of kidney dysfunction in TURP patients, and TURP might improve blood-urea and -creatinine levels. There were no significant associations between kidney recovery and kidney dysfunction with number of risk factors in TURP and pre-TURP patients and little chance of influencing kidney dysfunction (urea levels) occurrence in patients before TURP.

\section{Ethics Statement}

This study was performed in accordance with the Declaration of Helsinki. Data were gathered from the institution database with permission. Patient data were anonymized and confidentiality maintained throughout the study.

\section{Author Contributions}

All authors made a significant contribution to the work reported, whether in conception of the study, execution, acquisition of data, analysis, and interpretation, or all these areas, took part in drafting, revising, or critically reviewing the article, gave final approval to the version to be published, have agreed on the journal to which the article has been submitted, and agree to be accountable for all aspects of the work.

\section{Disclosure}

The authors certify that there are no conflicts of interest with any financial organization regarding the material discussed in the manuscript.

\section{References}

1. Zuhirman JD, Lestari P. Complication of transurethral resection of the prostate in benign prostatic hyperplasia patients. J Med Sci. 2016;50:(1):44-53.

2. Presti JC, Kane CJ, Shinohara K, Carroll PR. Neoplasms of the prostate gland. In: Smiths's General Urology. 17th ed. California: McGrawhill; 2008:348-355.

3. National Institute of Diabetes and Digestive and Kidney Diseases. Clinical Guidelines on the Identification, Evaluation and Treatment of Overweight and Obesity in Adults: The Evidence Report. U.S. Departement of Health and Human Service: Prostat Enlargement (Benign Prostat Hyperplasia); 2014.

4. Song J, Shao Q, Tian Y, Chen S. Lower urinary tract symptoms, erectile dysfunction, and their correlation in men aged 50 years and above: a cross-sectional survey in Beijing, China. Med Sci Monit. 2014;20:2806-2810. doi:10.12659/MSM.891180

5. Corona G, Vignozzi L, Rastrelli G, Lotti F, Cipriani S, Maggi M. Benign prostatic hyperplasia: a new metabolic disease of the aging male and its correlation with sexual dysfunctions. Hindawi Publishing Corporporation. ;2014. doi:10.1155/2014/329456

6. Taylor Benjamin L, William I. Electrosurgical transurethral resection of the prostate and transurethral incision of the prostate (monopolar technique). Can J Urol. 2015;22(Suppl 1):24-29.

7. Prostate Cancer. Enlarged Prostate: A Guide to Diagnosis and Treatment. United Kingdom: Prostate Cancer UK; 2015.

8. Lee BK, Vincent FG. Acute kidney injury and oliguria. In: McAninch JW, Lue TF, editors. Smith \& Tanagho's General Urology. 19th ed. Lange Mc Grow Hill; 2020:551-555.

9. Sabri M. Description of Benign Prostate Hyperplasia Patients with Transurethral Resection of the Prostate in Arifin Achmad Hospital, Pekanbaru [Scripsion]. Pekanbaru: Riau University; 2011.

10. Levey AS, Coresh J, Bolton $\mathrm{K}$, et al. K/DOQI clinical practice guidelines for chronic kidney disease: evaluation, classification and stratification. Am J Kidney Dis. 2002;39:S1-S266.

11. Mieszkalski GB, Keit J, Brady LW. The natural history of benign prostatic hyperplasia. In: Petrovich Z, Baert L, editors. Innovations in the Management of Benign Prostatic Hyperplasia. 1st ed. Berlin: Springer-Verlag; 1994:39-46.

12. Presti JC, Kane CJ, Shinohara K, Carrol PR. Neoplasms of the prostate gland. In: Tanagho EA, McAninch JW, editors. Smith's General Urology. 18th ed. New York: McGraw-Hill; 2013:350-373.

13. Sjamsuhidajat S, Karnadihardja W, Prasetyono TOH, Rudiman R. Surgery textbook. 3rd ed. In: Sjamsuhidajat-De Jong. Jakarta: EGC Medical Book Publicator; 2010:899-902.

14. Price SA, Wilson LM. Pathophysiology, clinical concepts and disease process. In: Pendit $\mathrm{BU}$, Hartanto $\mathrm{H}$, editors. The Journal of Pathology. 6th ed. Vol. 2. Jakarta: EGC; 2005:1320.

15. Utami R. The Incidence of Acute Kidney Injury Based on Akin Criteria in Intensive Care in Dr.Soedarso Hospital Tanjungpura, Indonesia in 2013 [Publication Manuscript]. Pontianak: Medical Faculty, Tanjungpura; 2015.

16. Hidayati N. Description of Prostate Specific Antigen Level in Benign Prostate Hyperplasia with Urinary Retension in Arifin Achmad Hospital, Pekanbaru, Indonesia in January 2011-December 2015 [Scripsion]. Pekanbaru: Riau University; 2016. 
17. Selzer R. Chronic Kidney Disease (CKD): Clinical Practice Recommendations for Primary Care Physicians and Healthcare Providers-A Collaborative Approach. 6th ed. Divisions of Nephrology \& Hypertension and General Internal Medicine, Henry Ford Health System; 2011.

18. Sukandar E. Urinary tract infection in adult patients. In: Sudoyo AW, editor. Textbook of Internal Medicine. Jakarta: Internal Medicine Publication Center; 2009:1008.

19. Isroin L. Risk factor prevalency of chronic kidney function [Internet]. Eprints.umpo.ac.id; 2014. Available from: http://eprints.umpo.ac.id/ 2521/1/PREValensi\%20faktor\%20risiko.pdf. Accessed August 27, 2021.

20. Adhiatama A, Wahab Z, Widyantara I. Analysis of Factors Related to Chronic Kidney Failure in Hemodialysis Patients in Tugurejo Hospital, Semarang, Indonesia. Medical Faculty. Muhamadiyah University Semarang; 2017:1-10.

21. Hervinda S, Tjekyan S. Prevalency and risk factors of chronic kidney failure in Dr. Mohammad Hoesin Hospital, Palembang, Indonesia. 2012. MKS. 2014;4:275-281.

22. Smith E. Pyelonephritis, renal scarring, and reflux nephropathy: a pediatric urologist's perspective. Pediatr Radiol. 2007;38 (S1):76-82. doi:10.1007/s00247-007-0587-x

23. Hsiao C, Yang H, Hsiao M, Hung P, Wang M. Risk factors for development of acute kidney injury in patients with urinary tract infection. PLoS One. 2015;10(7):e0133835. doi:10.1371/journal. pone. 0133835

24. Venkatesh L. Acute pyelonephritis - correlation of clinical parameter with radiological imaging abnormalities. J Clin Diagn Res. 2017;11 (6):TC15-TC18.

25. Rollino C, Beltrame G, Ferro M, Quattrocchio G, Sandrone M, Quarello F. Acute pyelonephritis in adults: a case series of 223 patients. Nephrol Dial Transplant. 2012;27(9):3488-3493. doi:10.1093/ndt/gfr810

26. National Institute of Diabetes and Digestive and Kidney Diseases. Clinical Guidelines on the Identification, Evaluation and Treatment of Overweight and Obesity in Adults: The Evidence Report. U.S. Departement of Health and Human Service: Urinary Retention; 2014.

27. Vaidyanathan S, Selmi F, Hughes P, Singh G, Soni B. Urinary retention and acute kidney injury in a tetraplegic patient using condom catheter after partying: a preventable complication. Int Med Case Rep J. 2015;8:241-245. doi:10.2147/IMCRJ.S86295
28. Speakman M, Cheng X. Management of the complications of BPH/ BOO. Indian $J$ Urol. 2014;30(2):208-213. doi:10.4103/09701591.127856

29. Rule AD, Krambeck AE, Lieke JC. Chronic kidney disease in kidney stone formers. Clin J Am Soc Nephrol. 2011;6:2069-2075. doi: $10.2215 / \mathrm{CJN} .10651110$

30. Kartha G, Calle JC, Marchini GS, Monga M. Impact of stone disease: chronic kidney disease and quality of life. Urol Clin North Am. 2013;40:135-147. doi:10.1016/j.ucl.2012.09.004

31. Aristo D. Prognostic parameters of kidney function recovery in obstructive uropathy patients. Med Sci J. 2016;3(3):9-19.

32. Baskoro C, Rodjani A. Correlation Between Ureter Stone Size and Hidronephrosis Grade in Ureter Stone Patients. [Thesis]. Medical Faculty, University of Indonesia; 2013.

33. Singh I, Strandhoy JW, Assimos DG. Pathophysiology of urinary tract obstruction. In: Wein K, Novick P, editors. Campbell-Walsh Urology. 10th ed. Vol. 2. Philadelphia: Elseiver Saunders;2012:1087.

34. Kamal A. Estimation of blood urea (BUN) and serum creatinine level in patients of renal disorder. Ind J. 2014;4(4):199-202.

35. Samra M, Abcar AC. False estimates of elevated creatinine. Perm J. 2012;16(2):51-52. doi:10.7812/TPP/11-121

36. Zamzami Z. Blood urea and creatinine levels in obstructive uropathy patients due to benign prostate hyperplasia after transurethral resection of the prostate. Int $J$ Surg Med. 2019;5(1):18-22.

37. Riyach O, Ahsain M, Kharbach Y, et al. Bilateral ureteral obstruction revealing a benign prostatic hypertrophy a case report and review of the literature. J Med Case Rep. 2014;8:42. doi:10.1186/1752-1947-8-42

38. Thassinas D, Wattanachai V, Channatee B, Kriergeek P, PriyAtnana $T$. Irrigation with water during transurethral of the prostate (TURP) induces intravascular hemolysis. Asian Biomed. 2013;7:795-802.

39. Amar N. Prospective study of the effects of TURP on out-come, morbidity, and mortality in patients with non-dialysis requiring renal insufficiency. IOSR J. 2015;14(5):105-122.

40. Sarier M, Tekin S, Duman L, et al. Result of transurethral resection of the prostate in renal transplant recipients: a single center experience. World J Urol. 2018;36(1):99-103. doi:10.1007/s00345-017-2094-5

41. Volpe A, Billia M, Vidali MQ, et al. Transurethral resection of the prostate in kidney transplant recipients: urological and renal functional outcomes at long-term follow-up. BJUI. 2013;112(3):386-393. doi:10.1111/bju. 12030
Research and Reports in Urology

\section{Publish your work in this journal}

Research and Reports in Urology is an international, peer-reviewed, open access journal publishing original research, reports, editorials, reviews and commentaries on all aspects of adult and pediatric urology in the clinic and laboratory including the following topics: Pathology, pathophysiology of urological disease; Investigation and treatment of urological disease; Pharmacology of drugs used for the treatment of urological disease. The manuscript management system is completely online and includes a very quick and fair peer-review system, which is all easy to use. Visit http://www.dovepress.com/ testimonials.php to read real quotes from published authors. 